\title{
ATR Kinase Inhibitor BAY1895344
}

National Cancer Institute

\section{Source}

National Cancer Institute. ATR Kinase Inhibitor BAY1895344. NCI Thesaurus. Code C146807.

An orally available ataxia telangiectasia and Rad3-related (ATR)-specific kinase inhibitor, with potential antineoplastic activity. Upon oral administration, AT R kinase inhibitor BAY1895344 selectively binds to and inhibits the activity of ATR, which prevents ATRmediated signaling. This inhibits DNA damage checkpoint activation, disrupts DNA damage repair and induces apoptosis in ATR-overexpressing tumor cells. ATR, a serine/threonine protein kinase upregulated in a variety of cancer cell types, plays a key role in DNA repair, cell cycle progression and cell survival. 